\title{
The Dynamics of Street Vendors' Resistance in Bandung City
}

\author{
${ }^{1}$ RINA HERMAWATI, ${ }^{2}$ OEKAN S. ABDOELLAH, ${ }^{3}$ BUDHI GUNAWAN, ${ }^{4}$ SELLY \\ RIAWANTI ${ }^{5}$ NUNUNG RUNIAWATI ${ }^{6}$ CAROLINE PASKARINA
}

\begin{abstract}
${ }^{1234}$ Departemen Antropologi, Universitas Padjadjaran, Jalan Raya Bandung-Sumedang KM 21 Jatinangor, 5Departemen Administrasi Publik, Universitas Padjadjaran, Jalan Raya Bandung-Sumedang KM 21 Jatinangor, ${ }^{6}$ Departemen IImu Politik, Universitas Padjadjaran, Jalan Raya Bandung-Sumedang KM 21 email: 1rina.antrop@gmail. ; 2oekan.unpad.ac.id; 3budhigunawan03@unpad.ac.id; 4selly_riawanti@unpad. ac.id; 4c.paskarina@gmail.com; 4n.runiawati@unpad.ac.id ²oekan.unpad.ac.id, ${ }^{3}$ budhigunawan03@unpad.ac.id, ${ }^{4}$ selly_riawani@unpad.ac.id, 5 nruniawati.yahoo.com, ${ }^{6}$ cpaskarina@gmail.com,
\end{abstract}

\begin{abstract}
This research depicts the dynamics of street vendors' resistance to the city government's policy. The research applied qualitative approach with research strategy of case study. The research result showed that street vendors' strategies in dealing with the city government were devised in various ways, both covert and open ones. Covert resistance tended to be put up when street vendors were already in a weak position. However, when street vendors were in a firm position, they tended to choose open resistance. The theme of resistance was adjusted to the situation and policies imposed by the government. When eviction was carried out, street vendors' resistance was focused on the effort to ask for space for trading. When relocation was carried out, street vendors' resistance was put up to obtain strategic locations and empowerment programs. When the zoning system was applied, street vendors attempted to intervene in the criterion of green, yellow, and red zones.
\end{abstract}

Keywords: policy, resistance, street

\section{Introduction}

This article depicts the dynamics of street vendors' resistance to retain their place of business in public places by using the concept of resistance. Scott in his study on peasant resistance in Kedah, Malaysia, explained that resistance is any act(s) by member(s) of a subordinate class that is or are intended either to mitigate or deny claims (for example, rents, taxes, prestige) made on that class by superordinate classes (for example, landlords, large farmers, the state) or to advance its own claims (for example, work, land, charity, respect) vis-à-vis those super-ordinate classes (Scott, 2000). Foucault stated that resistance is always present together with power, and where there is power there is resistance (Foucault, 2002). Therefore, resistance has become the weapon of marginal people to undermine the domination of those who are considered to be stronger/more powerful.

The presence of street vendors in public places, which is considered to be a disturbance to the security, order, and beauty of the city, certainly has led to the response from the city government in the form of policies of eviction, relocation, and arrangement of street vendors. Street vendors interpret the policy as a threat to the continuance of their business considering that the business characteristic of street vending is to make use of centers of the crowd. In order to retain their business in public places, street vendors have put up some resistance.

Studies on street vendors' resistance have been conducted in a variety of perspectives, among them social interaction, social network, and power relations (resistance, accommodation, conflict) (Aisyah, 2012; Alisjahbana, 2006; Gibbings, 2011; Hanser, 2016; Hermanto, 2011; Mustafa, 2008; Setia, 2008; Siswono, 2009; Turner \& Schoenberger, 2012) 
A study on the organizing of street vendors (Setia, 2008) has shown the important role of street vendor organizations in overcoming some problems, whether they stem from internal factors (such as conflict among street vendors) or external ones (such as those related to the government's policy). This study concludes that the role of street vendor organizations or groups is quite crucial in negotiating several necessities and problems encountered by street vendors.

Other studies on street vendors' resistance show that the model of street vendor arrangement which always uses a repressive approach and negative stigma deliberately attached by the city government to the informal sector has caused obstinate behavior among street vendors. The obstinate behavior is shown in the form of resistance to the eviction policy, in which street vendors "disappear" just when the eviction is conducted, just to reappear, to be evicted again, to reappear, and so forth and so on (Alisjahbana, 2006; Gibbings, 2011; Hanser, 2016; Hermanto, 2011; Setia, 2008; Turner \& Schoenberger, 2012). When the resistance is considered to be ineffective, street vendors will conduct negotiations and make an accommodation with the apparatus and local thugs to retain their presence in public places (Siswono, 2009). As part of negotiations and accommodation, some amount of "bribery" usually becomes an effective way to establish these relations.

Another effort made by street vendors is to establish interaction with some parties, buyers, good suppliers, government institutions, and non-governmental organizations (NGOs), in the forms of transaction, actualization, cooperation, association, conflict, and coordination (Mustafa, 2008). Transaction and cooperation are the relations which are mutually beneficial in terms of materialistic and economic aspects with other street vendors, parking attendants, and suppliers. Actualization is the efforts to socialize ideas or the effort to show the presence of street vendors through the dissemination of identities and aspiration through the media. Association is the relations established by founding organizations or paguyuban (associations) to maintain the interest of the group and also to strengthen positions and relations. Conflict is the relations which have the characteristic of a collision of values and interest found in two forms of relations, vertical relations (between street vendors and NGOs on the one side and the apparatus and stores on the other side, ) and horizontal relations (between street vendors and pedestrians). Meanwhile, coordination is a form of relations in an institutional frame, such as coordination with offices and institutions of the city government. The six patterns of interaction have broadened street vendors' social network that they have bargaining power against the city government.

The articles above are useful for describing street vendors' resistance to the city government's policy. However, this article would provide a more detailed depiction of the dynamics of street vendors' resistance and also would answer the question why the forms of resistance put up by street vendors may vary although they are in the same location. Some street vendors put up harsh frontal resistance but some of them put up covert resistance.

\section{Research Method}

This research used qualitative method with the research strategy of case study. Based on interviews with informants from the government apparatus (Satpol PP (the Civil Service Police Unit) and Dinas Koperasi, KUKM dan Indag (the Office of Cooperatives, Small and Medium-sized Enterprises, and Industry and Trade) and also board members of the association of street vendors at the red zone (the zone where street vendors are not allowed to trade), two locations which are interesting to examine were obtained, in which the two locations depicted different case characteristics: 1 ) street vendors at Jalan $X$ in the Region of Sumur Bandung, considered to be the government's "victory" in overcoming the problem of street vendors because they were successfully relocated to the basement of mall $A$ and 2 ) street vendors at Jalan $Y$ in the Region of Andir, considered to be street vendors' "victory" in influencing the government's policy, in which they were still allowed to operate at Jalan $Y$ under certain conditions.

Activities of data collection were conducted through participant observation, in-depth interviews, and documentation. Participant observation was conducted to find out directly the trading activities of street vendors, the atmosphere and interaction they established, and also tactics and strategies they developed to fight for their places of business. In these observation activities, the author attempted to follow street vendors' 
activities, whether when they were conducting trading activities, holding informal meetings, and staging demonstrations.

Interviews were conducted with ten street vendors at Jalan $X$ and Jalan $Y$, board members of the association of street vendors, Satpol PP (the Civil Service Police Unit), Dinas Koperasi, KUKM dan Indag (the Office of Cooperatives, Small and Medium-sized Enterprises, and Industry and Trade), and the Regional Development Planning Agency. In broad outline topics of interviews were related to characteristics of street vendors at the research location, street vendors' attitude towards the government's policy (eviction, relocation, arrangement, and supervision) and street vendors' actions to address the policy.

Documentation materials used in this research were particularly related to the characteristics and distribution of street vendors, their organizations, and their strategies for addressing the city government's policy.

\section{Street Vendors' Responses to the City Government's Policy: A Study on Street Vendors at Jalan $X$ in the Region of Sumurbandung and Street Vendors at Jalan $Y$ at the Region of Andir}

Resistance has a variety of forms, both covert and open ones. Covert resistance is unorganized, spontaneous, and it avoids conflict with the power holder. Some forms of covert resistance are, among others, gossip, backbiting, and pretending to be obedient. Meanwhile, open resistance is organized, requires planning and coordination, and has revolutionary consequences, like demonstrations, physical fights, and wars of words (Scott, 2000). This section would examine how street vendors used these forms of resistance in responding to the city government's policy, whether it is the policy of eviction, relocation, or arrangement.

\section{Street Vendors at Jalan $X$ in the Re- gion of Sumurbandung: A Long Road to Relocation}

Street vendors at Jalan $\mathrm{X}$ in the Region of Sumurbandung represented characteristics of street vendors who had migrant background with an education level of high school on average. Some of them migrated to Bandung to find work in formal sector. However, there were also migrants who from their first arrival had planned to be street vendors, following the footsteps of relatives or friends who had succeeded in their career as street vendors.

The year of 2001 saw the "golden" age of street vendors at Jalan X. At that time the number of street vendors reached 360 with a variety of traded goods, such as bags, shoes, VCDs, wallets, belts, clothes, food, drink, study desks, animals, and others. However, since 2005 up to present they have changed their wares to accessories of mobile phones, such as mobile phone covers, mobile phone wallets, mobile phone cases, batteries, chargers, et cetera.

It can be said that their earnings were more than sufficient, in which their daily turnover ranged between Rp 500,000,- to Rp $4,000,0000,-$ with an average profit of $30 \%$. The high income made them comfortably operate their business at Jalan X, and even more, they considered Jalan $X$ to be their source of livelihood.

\section{Efforts Made by Street Vendors at Jalan $X$ in the Region of Sumurband- ung to Address the Policy of Street Vendor Eviction and Relocation}

Decree of the Mayor of Bandung No. 511.23/Kep.1322-Huk/2001 on Locations Free from Activities of Street Vendors in Bandung City has determined that Jalan $X$ is one of the street-vendor-free locations. It made activities of eviction start to become street vendors' everyday "menu". Being oppressed and powerless, they could do nothing but have gossips with their fellow street vendors. Expressions like "The government is annoying", "The government pays no attention to the fate of the poor", and "The government completely sides with businessmen" were their forms of dissatisfaction with the eviction policy.

In 2003, street vendors at Jalan X began to disappear as a result of intensive eviction drive carried out by the government. After street vendors had disappeared, the Civil Service Police Unit began to lessen their supervision. Street vendors took advantage of this situation to make "attempts" to run their business again in the region.

Street vendors' experience of being chased away by the Civil Service Police Unit 
made them begin to learn how to face the apparatus. They began to choose to play cat and mouse, running away when a raid was carried out and returning when the apparatus had left the place. Although this way was considered to be effective, some street vendors admitted that they were tired of this situation. Some of them then attempted to befriend the apparatus to obtain information on the eviction plan by giving them a bribe.

However, it was not always the case that the eviction plan leaked out. Sometimes their goods were confiscated and loaded onto the officers' trucks. All researchers' informants had experience of confiscation of their goods and they were forced to have dealings with the officers to get their goods back.

Apart from being evicted, they had also been relocated to the Temporary Relocation Center for Vendors (TPPS) of Gedebage. In Gedebage they lasted only for a month before deciding to return to Jalan $X$. The reason was that the wares they sold were not suitable for the characteristic of Gedebage Market so that they experienced a decrease in their income. Besides that, they were used to living at Jalan $X$ and they found it hard to begin a new life in the new place. Street vendors' decision to return to Jalan $\mathrm{X}$ was a rational act. As proposed by Giddens (Giddens, 2010), basically people act because they have a certain rationality and based on intentional object and purpose. Street vendors make a choice they believe will bring the expected utility (profit) and they act according to the choice.

In choosing the location of their business, street vendors will consider four factors, (1) there is an accumulation of people doing activities jointly at the relatively same time, all day long, (2) it is located in a particular area that constitutes centers of urban economic activities and centers of urban non-economic activities, but frequently visited by many people, (3) it facilitates relation between street vendors and potential buyers, even though it is conducted in a relatively narrow space, and (4) it does not require the availability of public facilities and public service utilities (Widjajanti, 2009). This condition made the relocation of street vendors to TPSS ended in failure.

Their return to Jalan $X$ certainly brought the consequence of being chased away again by the Civil Service Police Unit. Once again they employed strategies of playing cat and mouse, befriending the apparatus, and redeeming their wares. In this uncertain situation, they began to think about strengthening their forces. Although they had not yet founded a formal organization, at that time they began to hold joint activities, such as arisan (regular social gatherings where members contribute a set amount of money and take turns at winning the aggregate sum), sport, motorbike touring, and others. These activities, which were coordinated by one of the senior street vendors, then became the forerunner of the founding of a street vendor cooperative.

This cooperative then became a forum for maintaining a good relationship and also a means of instilling familial values among street vendors at Jalan X. Apart from social activities (arisan, savings and loan, recreation, motorbike touring, and sport), for street vendors the cooperative also became a means of problem-solving, ranging from family problems, problems with their fellow street vendors, to problems with the city government. Organizations play an important role in trade sector. (Fitlayeni, Rinel, Marleni, 2015) in their study on market traders found three roles of informal organizations, (1) strengthening the social network with fellow traders, (2) enhancing social network with buyers, and (3) improving solidarity.

To strengthen its position, this cooperative joined one of street vendor associations in Bandung City. Not all street vendors agreed to join this association. This was due to the obligation to pay monthly dues. According to those who disagreed, these monthly dues indicated that the support provided by the association A was only motivated by material profit.

Street vendors who were not willing to join the association A preferred to ask for support from NGOs and university students to face eviction and relocation. The support from NGOs and university students enabled them to have some knowledge of the government policy and techniques for arguing with the apparatus. Hence, when the street vendors got evicted, they would engage in an argument, questioning the legal ground for the eviction and also asking for a solution to the continued existence of their means of livelihood.

When their wares were confiscated by officers, NGOs and university students usually would provide advocacy support. When eviction started to be intensive, they would unhesitatingly stage demonstrations and 
this tactic was usually effective in reducing the intensity of eviction conducted by the government.

Meanwhile, the street vendor cooperative chose to obey the government. One form of their obedience was a reduction in the number of street vendors and scheduling of the operating hours of street vendors. Another method employed by the cooperative is to make an effort to establish communication with the city government. Provided with the Local Bylaw No. 2 Year 2009 on Management of Modern and Traditional Markets which regulating the obligation of modern markets to provide $10 \%$ of the area for micro, small, and medium enterprises, in 2010 they proposed a concept of relocation of street vendors at Jalan $X$ to a shopping center (mall A) at the same street.

The proposal for relocation got no response from the government. In addition, among street vendors themselves, there had not been an agreement on the relocation. Some of them were doubtful and not convinced that they would earn the same amount of income at the relocation site. The situation made street vendors at Jalan $X$ divided into two groups, the first group that agreed on relocation and the second group that did not want relocation.

The first group was identified as the group that had more capital than the second one. It indicates that capital affects the attitude shown by street vendors in dealing with relocation. The same condition occurs in Thailand, where street vendors are divided into two characteristics, the new generation and the old generation of street vendors (Maneepong, Chuthatip, 2013). Street vendors that more often violate the zonation regulation come from the old generation. The reason is that they cannot afford the space rent. Meanwhile, street vendors from the new generation tend to be easier to control because they operate at legal places rented out by the government or private companies and their target markets are upper middle consumers. Some forms of resistance have emerged in Thailand, with a background of corruption or acts of violence committed by the apparatus when they expelled street vendors from their places of business. Open resistance was put up by street vendors through demonstrations (group resistance) to fight against any violence committed by the apparatus to street vendors. This action was dominated by street vendors from the old generation. Meanwhile, street vendors from the new generation tended to put up covert resistance. They refused to stage demonstrations because they worried about a negative image that might diminish their business. As a form of resistance, they preferred to rent private places, despite a higher rental price, to avoid corruption committed by the apparatus.

\section{Street Vendors' Attempts in Dealing with the Policy on Arrangement and Supervision of Street Vendors}

In 2013 the City Government of Bandung decided to relocate street vendors at Jalan X. The relocation site offered was the basement of the city square in front of the Grand Mosque, but the street vendors refused it, on the reasoning that it was not suitable for the majority products they sold, mobile phone accessories. The City Government proposed another alternative, Gedebage and Pamoyanan Market at Jl. Dursasana. By the same reason, they also refused both places. They kept on insisting to be relocated to mall A. Eventually, the city government conducted negotiations with the management of mall $A$ and they reached an agreement to provide a place in the basement of mall $A$.

Despite the agreement, street vendors had not been willing to occupy the relocation site. They thought the place provided by the mall was not sufficient and it could not accommodate all street vendors of Jalan $X$ so that they decided to remain at the street. Once again the street vendors faced up to the Civil Service Police Unit, which led to some quarrels and two physical fights.

These tensions eventually opened the eyes of the City Government of Bandung to reopen a dialogue with street vendors. The dialogue was quite effective, since it has been proven that in February 2014 the street vendors were successfully relocated from Jalan $X$ to mall A. However, the problem of the site reappeared to be a subject of debate when the street vendors were reluctant to be located at P3, considering that it was just a parking area rarely passed through by visitors. Once again, they entered into negotiations with the management of mall $A$ and eventually the street vendors were placed at $P 1$, which was quite busy because it was the entrance for visitors from the parking area to the mall lobby. In addition, street vendors had to pay stall rent and display money. The amount was felt to be burdensome for some street vendors of Jalan $\mathrm{X}$, and hence 
the negotiation process was started again, which involved legislators from the Local House of Representatives of Bandung City. Finally, the City Government facilitated a credit grant of Rp 210,000,000,- through People's Credit Bank which was channeled through the Cooperative $X$. This credit was used for paying stall /display money of Rp $1,500,000 /$ person and the first-month rent of Rp 1,500,000/person for 70 street vendors.

Over time, nine street vendors refused to be relocated and they decided to return home or find other locations, while 61 people were willing to occupy the basement of mall A. For the Cooperative, relocation was the best option and it was the fruit of their struggle as they were the party that proposed mall $A$ as the relocation site.

However, conditions at the relocation site brought about the new dynamics. Slack sales triggered debate among the street vendors. Some street vendors started to be impatient waiting for buyers. Conditions were much worse because some months before the relocation they could not sell their wares due to the dispute with the officers.

Seeds of conflict over pro and contra of relocation intensified again and gave rise to two factions of street vendors. The first faction under the Cooperative of street vendors still agreed on the first commitment of relocation while the second faction which comprised 35 people opted to return to the street.

\section{The First Faction of Former Street Vendors at Jalan $X$ in the Region of Sumurbandung}

It was not easy for the board members of the Cooperative to persuade the street vendors to stay at the basement of mall $A$. $A$ drastic decrease in sales became a particular subject of debate among them. The board members attempted to convince them that becoming informal sellers was much better than becoming street vendors.

To change the mindset of these former street vendors, the board members tried to instill a new identity that they were not street vendors anymore, they were sellers of the informal sector. Not only regulating the term, but the board members also imposed the regulation of dress code and working hours. The former street vendors were required to wear neat clothes and shoes. Another regulation instilled among them was to keep their trading area clean. Meanwhile, to attract consumers, the board members suggested that the sellers change the design of their stalls every three months and change the interior, lighting, et cetera every year.

Besides that, the board members attempted to instill identities that they were strong and independent. They were not allowed to depend on the government or other parties. Therefore, the board members rejected the involvement of NGOs or other parties in fighting for their aspiration.

At present, the struggle of the cooperative is directed to a sustainable relocation program (promotion and capital facilitation) through communication with various parties, particularly academicians, university students, and observers of social issues. The communication is made through informal discussion or distribution of leaflets and proposals containing the issue of relocation.

\section{The Second Faction of Former Street Vendors at Jalan $X$ in the Region of Sumurbandung}

The second faction is former street vendors at Jalan $X$ who from the beginning have had doubts about the relocation. Their doubts came true when there were few consumers at the relocation site. At the same time, the city government was considered to not provide any support, both in terms of promotion and empowerment.

This situation was worsened by the obligation to pay stall rent of Rp1.5 million per month, which was considered to be not in balance with their sales there. Street vendors of the second faction decided to return to Jalan X. As a consequence, they had to face the City Government again. Activities of eviction which were conducted every day made them find it hard to generate an income.

Realizing that their position was weak, they attempted to consolidate their position by founding their own organization which was named the Organization $B$. In fighting for their aspiration, the second faction opted to stage demonstrations and to have audiences with the officials. Demonstrations had strategic values to attract attention from the public, the mass media, the city government, and legislators from the Local House of Representatives of Bandung City.

Negotiations were conducted with the 
city government, particularly on the area of the stall and stall rent. After reaching an agreement, eventually, street vendors of the second faction decided to return to the relocation site. Their new relocation site was better than that of street vendors of the first faction, both in terms of the area and the interior. The success of their struggle could not be separated from the support of NGOs, social activists, and the mass media, both the print and online media. NGOs and social activists were very helpful in formulating strategies and tactics for their struggle, for instance, formulating issues of demonstrations, techniques of struggle, and negotiations with the city government. Meanwhile, the mass media were very helpful in spreading the occurring problem and attracting attention from the public, hence encouraging the mayor to adopt a policy that sided with street vendors. Another medium which was frequently used was Twitter. Through Twitter, they often expressed street vendors' grievances against the government policy, which was perceived to not side with street vendors, or criticized urban development conducted by the City Government.

\section{Street Vendors at Jalan $Y$ in the Region of Andir: Struggle towards Change in the Zoning Status}

Similar to Jalan $X$, Jalan $Y$ is one of the red zones, considering that Jalan $Y$ has a status as a national road. The presence of street vendors at Jalan $Y$ cannot be separated from activities of $C$ Market occurring around the location. Activities of the market start in the evening and continue until the next morning, offering a variety of basic necessities and various special and cheap snacks. The liveliness of $C$ Market attracts hundreds of street vendors to earn their living along Jalan Y.

Characteristics of street vendors of Jalan $Y$ were very different from those of street vendors at Jalan $X$. The majority of street vendors at Jalan $Y$ were of Sundanese ethnicity that came from Bandung Regency, West Bandung Regency, and Bandung City. Although there were also some street vendors from Sumedang and Garut, they had been lived in Bandung for a long time, only they had not yet arranged for resident's ID card.

The majority of the street vendors sold vegetables, whose consumers were vegetable peddlers, and small items like cooking oil, noodles, snacks, and others, whose consumers mostly were owners of food stalls. Besides that, there were also some sellers that sold food and drinks like martabak (a type of pancake), milk coffee, and noodles, who were frequently visited by consumers and other sellers. The number of street vendors at Jalan $Y$ was 630 and they operated from 05.00 p.m. to 08.00 am the next morning.

On average, they had an education level of elementary school to high school. Some of them made street vendors their first profession because they found it hard to get other jobs, but there were also some street vendors who used to be factory workers that had been laid off. Numerous consumers who visited Jalan $Y$ made them enjoy a quite high turnover, ranging from $\mathrm{Rp} 1,000,000$,- to Rp4,000,000,- per day.

\section{Attempts Made by Street Vendors at Jalan $Y$ to Deal with the Policy of Eviction and Relocation}

The presence of street vendors at Jalan $Y$ certainly led to responses from the government in the form of eviction. In dealing with the policy of eviction, they employed strategies which were not very different from those of street vendors at Jalan $X$, that is, to play cat and mouse. They would disappear when the eviction was conducted and return to sell their wares after the eviction had finished. When their wares were confiscated, they usually negotiated with the apparatus by giving them bribes. However, this strategy was not always successful. Sometimes the officers refused to negotiate.

Considering that the strategy of negotiations they employed was not effective, they preferred to rely on the strategy of playing cat and mouse until subsequently they were relocated to $D$ Market. At first, they tried to obey the policy of relocation, but a slack market made them only able to stay at the relocation site for a month. This was because there were still some street vendors at Jalan $Y$ so that consumers preferred to buy goods there.

Slack sales at D Market forced the street vendors to return to Jalan $\mathrm{Y}$. At that time, they attempted to unite and oppose the policy of relocation by staging demonstrations, supported by NGOs. It turned out that demonstrations did not yield optimum results. The government did not provide solutions to 
the problem of street vendors.

Returning to Jalan $Y$ meant that they faced the apparatus again. The tactic of playing cat and mouse was the only way they could do. In this uncertain situation, street vendors attempted to coordinate themselves. They held informal meetings, discussing the situation and solutions to the problem they were facing.

At that time the street vendors admitted that they found it hard to understand the government policy. "To whom should we complain? How should we sell goods for a living? Where? At that time, nobody explained to us, nobody gave us an understanding of what we violated." One of the street vendors, who was appointed as the coordinator, attempted to find support from some parties, but unfortunately, the NGO that previously assisted them to stage demonstrations at D Market did not show any intensive concern.

Amidst their confusion, the coordinator of street vendors obtained information on the person they perceived to be able to guarantee their presence in public places. This information was obtained from some street vendors in other regions who also had the same fate, being chased away by the officers. Based on the information, in 2003 street vendors at Jalan $Y$ join the association $B$.

The street vendors perceived the association $B$ as a bridge connecting the City Government to the street vendors at Jalan $Y$. Through the association B, street vendors at Jalan $Y$ knew the city government's policy on street vendors, the government's program concerning street vendors, and also differences in interest between the city government and street vendors. Besides that, the association $\mathrm{B}$ also acted as a conveyor of street vendors' aspiration to the city government.

After joining the association $B$, the resistance tactic of street vendors at Jalan $Y$ changed. While previously they only opted for confrontational methods or playing cat and mouse, after joining the association of street vendors, they completed the resistance tactic with the methods of cooperation, particularly with the regional apparatus and the Civil Service Police Unit. One of their attempts was to give "coordination money" to thugs of the apparatus. This method was felt to be quite effective in providing safety feeling to the street vendors; at least they could obtain leaked information on eviction.

\section{Attempts Made by Street Vendors at Jalan $Y$ to Deal with the Policy of Arrangement and Supervision}

The imposition of the Local Bylaw No. 4 the Year 2011 which regulating Jalan $Y$ as one of the red zones has made Jalan $Y$ as one of the targets of arrangement conducted by the city government. In this uncertain situation, street vendors attempted to open communication with the City Government through the association $\mathrm{B}$. The attempt was made through direct negotiations with the Mayor, which resulted in an agreement on permission to trade for street vendors at Jalan $\mathrm{Y}$.

In this dialog, the association B conveyed the situation specific to Jalan $Y$, where there was a spillover market that was supported by the economic and political power of street vendors at Jalan Y. Economically, money circulation at Jalan $Y$ reached 1 million overnight. Meanwhile, politically the street vendors at Jalan $Y$ were well organized. Considering these factors, the Mayor agreed to give permission to street vendors to stay at Jalan $Y$, provided that they were willing to be regulated and obey the limitations of operating hours to $06.00 \mathrm{a} . \mathrm{m}$. The policy of arrangement was considered to be much better than the policy of relocation and eviction. Thanks to this policy of arrangement, they did not need to move from Jalan $Y$, but they were just required to obey the operating hours and to arrange the shape and color of their tents.

\section{Comparison of Resistance of Street Vendors at Jalan $X$ in the Region of Sumurbandung and That of Street Vendors at Jalan $Y$ in the Region of Andir}

Street vendors' opposition to the city government's policy was expressed in the form of resistance. The concept of resistance has emerged to organize the most important part of the opposition of marginal people which is expressed in daily lives. Scott has depicted in detail resistance put up by marginal people in the forms of acts like foot dragging, dissimulation, desertion, false compliance, pilfering, feigned ignorance, slander, arson, sabotage, and so on. These acts require little or no coordination or planning; they make use of implicit understandings and informal networks; 
they typically avoid any direct, symbolic confrontation with authority (Scott, 2000).

The study result shows that street vendors' resistance to the city government's policy can be classified into individual and collective resistance. Forms of individual resistance vary, ranging from open resistance (arguing with the apparatus, playing cat and mouse, physical resistance) to covert resistance (pretending to be obedient and cooperating with the apparatus).
Covert resistance constitutes political action commonly carried out by dominated people to avoid large consequences. Scott called these forms of resistance everyday forms of resistance, whose presence is almost ignored (Scott, 1999). These various methods were carried out alternately or sometimes simultaneously to respond to both eviction and relocation. This individual action tended to be unplanned and self-helping; hence this kind of resistance was easily put down by the apparatus.

Table 1

A Comparison of Street Vendors at Jalan $X$ and Jalan $Y$

\begin{tabular}{|c|c|c|c|c|}
\hline \multirow[t]{2}{*}{ No } & \multirow{2}{*}{$\begin{array}{c}\text { Comparison } \\
\text { Elements }\end{array}$} & \multicolumn{2}{|c|}{ Street Vendors at Jalan $X$} & \multirow{2}{*}{$\begin{array}{c}\text { Street Vendors at } \\
\text { Jalan Y }\end{array}$} \\
\hline & & Faction I & Faction II & \\
\hline 1 & $\begin{array}{l}\text { Organization of Street } \\
\text { Vendors } z\end{array}$ & $\begin{array}{l}\text { Coopera-tive } \\
\text { affiliating with the } \\
\text { associa-tion A }\end{array}$ & Associa-tion & $\begin{array}{l}\text { Associa-tion and } \\
\text { Coopera-tive }\end{array}$ \\
\hline 2 & $\begin{array}{l}\text { Character of } \\
\text { organization }\end{array}$ & Local & Local & Regional \\
\hline 3 & $\begin{array}{l}\text { Leaders of } \\
\text { organization }\end{array}$ & $\begin{array}{l}\text { The wives of street } \\
\text { vendors (cooperative) }\end{array}$ & Local street vendors & $\begin{array}{l}\text { Former street } \\
\text { vendors, political } \\
\text { activists }\end{array}$ \\
\hline 4 & $\begin{array}{l}\text { Members of } \\
\text { organization }\end{array}$ & $\begin{array}{l}\text { At first } 70 \text { and } \\
\text { decrea-sing to } 35\end{array}$ & 35 & 4,000 \\
\hline 5 & $\begin{array}{l}\text { Goals of the } \\
\text { organization }\end{array}$ & 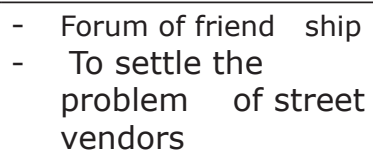 & $\begin{array}{ll}- & \text { Forum of friend } \\
& \text { ship } \\
\text { - } & \text { To settle the problem } \\
& \text { of street vendors }\end{array}$ & $\begin{array}{ll}\text { - } & \text { Forum of friend } \\
& \text { ship } \\
\text { - } & \text { To settle the problem } \\
& \text { of street vendors }\end{array}$ \\
\hline 6 & $\begin{array}{l}\text { The struggle of the } \\
\text { organization }\end{array}$ & Relocation to mall $\mathrm{A}$ & Staying at Jalan $\mathrm{X}$ & $\begin{array}{l}\text { An arrange-ment of } \\
\text { street vendors }\end{array}$ \\
\hline 7 & $\begin{array}{l}\text { The relationship } \\
\text { among street vendors }\end{array}$ & $\begin{array}{l}\text { A rift among } \\
\text { street vendors }\end{array}$ & $\begin{array}{l}\text { A rift among street } \\
\text { vendors }\end{array}$ & $\begin{array}{l}\text { United in facing the } \\
\text { city govern-ment }\end{array}$ \\
\hline 8 & $\begin{array}{l}\text { Attempts in fighting } \\
\text { for places of business }\end{array}$ & $\begin{array}{ll}\text { - } & \text { Playing cat and } \\
& \text { mouse } \\
\text { - } & \text { Accom modation } \\
\text { - } & \text { Establish ing } \\
& \text { organiza-tion } \\
\text { - } & \text { Demon stration } \\
\text { - } & \text { Nego tiation } \\
\text { Physical fight } \\
\text { - Submitt ing a } \\
\text { proposal for relocati } \\
\text { on }\end{array}$ & $\begin{array}{ll}\text { - } & \text { Playing cat and } \\
& \text { mouse } \\
\text { - } & \text { Accom modation } \\
\text { - } & \text { Establish ing } \\
& \text { organiza-tion } \\
\text { - } & \text { Demon stration } \\
\text { - } & \text { Nego tiation } \\
\text { - } & \text { Physical fight } \\
\text { - } & \text { Rejecting relocation }\end{array}$ & $\begin{array}{l}\text { - Playing cat and } \\
\text { mouse } \\
\text { - Accom modation } \\
\text { - Joining larger } \\
\text { organization } \\
\text { - Demon } \\
\text { stration } \\
\text { - Nego tiation }\end{array}$ \\
\hline 9 & Social network & $\begin{array}{ll}\text { - } & \text { Academi cians } \\
\text { - } & \text { Artists }\end{array}$ & $\begin{array}{ll} & \text { NGOs } \\
\text { - } & \text { The mass media } \\
\text { - } & \text { Legal activists } \\
\text { - } & \text { Academi cians } \\
\text { - } & \text { Artists }\end{array}$ & $\begin{array}{l}\text { - } \text { NGOs } \\
\text { - Political Parties } \\
\text { - The Local House } \\
\text { of Representatives } \\
\text { of Bandung City } \\
\text { - Legal } \\
\text { activists } \\
\text { - Academi cians } \\
\text { - Banking institutions } \\
\text { ons city } \\
\text { - The govern ment } \\
\text { gon }\end{array}$ \\
\hline 10 & Result & Relocation & Relocation & Arrange ment \\
\hline
\end{tabular}


In this uncertain situation, collective consciousness to struggle together emerged. This consciousness was supported by informal meetings among street vendors, beginning from just hanging out and drinking coffee together, to intentionally planned meetings. In these meetings, there emerged informal leaders who were appointed by street vendors as their leader due to their age, knowledge, and critical attitude. This collective resistance was better planned and on the other side, it showed that street vendors did not easily surrender to the government's agenda; they put up resistance.

These leaders then coordinated street vendors to found local associations/ organizations, mobilize resources, and put up resistance to the government. It was supported by political structure of Indonesia which has been more open along with the reform era, marked by the increase in political participation and freedom of the press. In outline, differences between resistance characteristics of street vendors at Jalan $X$ and those of street vendors at Jalan $Y$ are as in Table 1.

The table 1 shows that there were similarities and differences of resistance characteristics of street vendors at Jalan $X$ and Jalan $Y$ in dealing with the city government's policy. The resistance put up by the association of street vendors at Jalan $Y$ was dominated by covert resistance by using the methods of dialogues, coordination, and negotiations, indicating that actually street vendors did not really obey the government's policy. The main reason was to retain their occupation to survive. Scott revealed the term hidden transcript proposing that dominated groups sometimes show obedience that they perform before the dominant group (on-stage) but there is off-stage performance beyond observation of the city government (Scott, 1999). It is affirmed by open resistance through demonstrations when negotiations reached a deadlock. It shows that open resistance was initiated by actions of covert resistance which were out of the observation of the city government.

Concerning street vendor organizations, street vendors of both locations all have associations and cooperatives, but characteristics of both organizations differ. Street vendors at Jalan $X$ of the Faction I join a regional-based local association whose leader is not a street vendor. Street vendors at Jalan $X$ of the Faction II opt to establish a local association, led by a local street vendor. Meanwhile, street vendors at Jalan $Y$ join an established organization with 4,000 members. Besides that, the street vendor organization $B$ has firm social networks with various mass organizations, NGOs, and political activists, considering that the leader of the organization has experience of being active in some mass organizations. This choice of relation has become one of the factors that make the end result of their struggle differ, considering that access to power owned by the organizations also differs. This access is affected by resources owned by the organization, such as fund and networks, including characteristics of the leader of organization.

Eventually, resistance put up by street vendors has made the government's policy on street vendors not able to thoroughly overcome the problem of street vendors. Although covert resistance does not have a big effect like open resistance, in a long-term it is able to diminish the city government's policy.

In order that the policy on street vendors is successfully implemented, there are at least five factors which are able to determine the success of policy implementation, i.e. communication, attitude of the implementer, resources, structure of bureaucracy, and commitment of the leader (Hardiyansyah, 2014). Taking the case of street vendors in Bandung City as an example, the most crucial factor in the implementation of the policy on street vendors is the commitment of the leader to consistently conduct the arrangement and eviction of street vendors.

\section{Conclusion}

Choices of forms of resistance put up by street vendors are very dynamic, depending on internal factors (resources of the organization and access to the source of power) and external factors (policy and the apparatus implementing the policy). When street vendors have powerful resources (internal unity and social networks) and also access to power, they tend to opt for negotiations. Meanwhile, when street vendors feel weak, they tend to opt for covert resistance (playing cat and mouse, bribing, gossiping) and open one (arguing, staging demonstrations). Besides that, the city government's policy and the attitude of the apparatus that implement the policy also affect the choice of resistance. When the government implements the policy of eviction, 
street vendors tend to refuse it and ask for solutions concerning the place of business. When the government implements the policy of relocation, street vendors ask for strategic places which are easy to reach by visitors, promotion, and facilitation of financing.

\section{References}

Aisyah, U. (2012). Pedagang Kaki Lima Membandel di Jawa Timur. Jurnal Masyarakat Dan Kebudayaan Politik, 25(1), 47-55.

Alisjahbana. (2006). Marginalisasi Sektor Informal Perkotaan. Surabaya: ITS Press.

Fitlayeni, Rinel, Marleni, E. (2015). Strategi Organisasi Informal Menjaga Persistensi Pasar Tradisional di Kecamatan Padang Barat. Mimbar, 31(1), 61-70.

Foucault, M. (2002). PowerPower/Knowledge, Wacana Kuasa/Pengetahuan : Wawancara Pilihan dan Tulisan-tulisan lainnya 1972-1977 (Penerjemah Yudi Santosa). Jogjakarta: Bentang Budaya.

Gibbings, S. L. (2011). Unseen Powers: Transparency and Conspiracy in a Street Vendor Relocation in Yogyakarta, Indonesia. ProQuest Dissertations and Theses.

Giddens, A. (2010). Teori Strukturasi Dasardasar Pembentukan Struktur Sosial Masyarakat. Yogyakarta: Pustaka Pelajar.

Hanser, A. (2016). Street Politics: Street Vendors and Urban Governance in China. China Quarterly. https://doi.org/10.1017/ S0305741016000278

Hardiyansyah, R. E. (2014). Model Implementasi Kebijakan Publik dalam
Pengelolaan Sampah dan Kebersihan Kota Palembang. Mimbar, 30(1), 108-117.

Hermanto, D. (2011). Gerakan Sosial Pedagang Kaki Lima (Studi tentang Hegemoni pada Pedagang Kaki Lima di Pasar Bambu Kuning Kota Bandar Lampung. Humanus, $X(1)$.

Maneepong, Chuthatip, J. C. W. (2013). A New Generation of Bangkok Street Vendors: Economic Crisis as Opportunity and Threat. Cities: The International Journal of Urban Policy and Planning, 34, 37-43.

Mustafa, A. A. (2008). Model Transformasi Sosial Sektor Informal Sejarah, Teori dan Praksis Pedagang Kaki Lima. Malang: InTrans Publishing.

Scott, J. C. (1999). Domination and the Arts of Resistance: Hidden Transcripts. New Haven: Yale University Press.

Scott, J. C. (2000). Senjatanya Orang-orang yang Kalah (Penerjemah A. Rahman Zainnudin). Jakarta: Yayasan Obor Indonesia.

Setia, R. (2008). Ekonomi Informal Perkotaan. Bandung.

Siswono, E. (2009). Resistensi dan Akomodasi : Suatu Kajian Tentang Hubungan-Hubungan Kekuasaan Pada Pedagang Kaki-Lima (PKL), Preman dan Aparat di Depok, Jawa Barat. Jakarta.

Turner, S., \& Schoenberger, L. (2012). Street vendor livelihoods and everyday politics in Hanoi, Vietnam: The seeds of a diverse economy? Urban Studies. https://doi. org/10.1177/0042098011408934

Widjajanti, R. (2009). Karakteristik Aktivitas Pedagang Kaki Lima pada Kawasan di Pusat Kota Studi Kasus: Simpang Lima Semarang. Teknik, 30(3), 162-171. 